\title{
Composition and sensory properties of sour cherry cultivars
}

\author{
Bánáti, D. ${ }^{1}$, Tóth-Markus, M. ${ }^{1}$, Adányi, N. ${ }^{1}$, Boross, F. ${ }^{1}$, Vámos-Falusi Zs. ${ }^{1}$, \\ Daood, H.G. ${ }^{1}$, Szabó, T. ${ }^{2}$ \& Nyéki, J. ${ }^{3}$ \\ ${ }^{1}$ Central Food Research Institute, Hungary, H-1022 Budapest, Herman Ottó Street 15 \\ ${ }^{2}$ Research and Extension Centre for Fruit Growing, Hungary, H-4244 Úffehértó, \\ Vadas-tag 2 \\ ${ }^{3}$ Institute for Research and Development Centre of Agricultural Sciences and Engineering, \\ University of Debrecen, Hungary, H-4032 Debrecen, Böszörményi Str. 138
}

\begin{abstract}
Summary: Fruits of different sour cherry varieties cultivated, in 2008 and 2009, under organic farming and integrated cultivation conditions were analysed for their quality attributes, antioxidant activity and subjected to sensory evaluation.. Average size, weight, soluble solids, titratable acidity, total polyphenols, free radical scavenging capacity expressed as Trolox equivalent (TEAC), copper and zinc were determined in freshly harvested fruits. The obtained results indicated that, the principal component analysis can separate and distinguish the seasons of fruit production. The farming system seemed to have slight effect on quality the fruit as compared to varietal factors (genotypes). However, the total polyphenol content was uniformly less in 2009. Total polyphenols and free radical scavenging activity were significantly higher in Bosnian type sour cherries, and outstanding in Amarelle type cultivar 'Pipacs'. There was no statistically significant difference between the sensory properties of cultivars tested by panels, except the case of 'Pipacs'. The organolaptic investigation showed marked preference to the fruits of Eva and Petri cultivars.
\end{abstract}

Key words: sour cherry, organic farming, integrated. antioxidant, polyphenols, sensory

\section{Introduction}

Sour cherry production became highly important in the past decades in Hungary. As a result of excellent national sour cherry breeding, exclusively cultivars bred in Hungary are grown. Sour cherry is produced on approximately $16 \%$ of fruit orchard areas, while North-Eastern Hungarian local sour cherry cultivars ('Újfehértói fürtös', 'Debreceni bőtermő', 'Kántorjánosi') give about 50\% of the total sour cherry orchard area of Hungary. As a result of breeding, these cultivars ripe continuously, their similar appearance assures a continuous cropping and homogeneous quality for fresh consumption and processing industry as well.

Szabó (2007) did not observe significant difference between the North-Eastern Hungarian cultivars investigated concerning main quality attributes of their fruits. But when certain compositional parameters were compared to the climatic database, close correlations were discovered. For example, the higher amount of rainfall in the vegetation season resulted in lower titratable acidity of the fruits. According to the results of panel tests of the processed products (juice, canned fruits, and deep-frozen fruits) those made from 'Petri' were the best (Szabó, 2007). Polyphenols and free radical scavenging capacity play an important role in health protection, prevention of both cardiovascular diseases and cancer. Sour cherries are a rich source of them, especially those belonging to the family of so called Bosnian sour cherry cultivars. Papp and co-workers (2010) pointed out the very high antioxidant capacity of an amarelle-type cultivar, Pipacs 1.

The objective of the present investigations was to get compositional and sensory data for different sour cherry varieties grown with different technologies including organic and integrated farming and at different provinces. The storability of main cultivars was also included in thus work.

\section{Materials and Methods}

\section{Materials}

Sour cherries cultivated under integrated conditions were obtained from the Research Institute for Fruit Growing and Ornamentals in Újfehértó, whereas, the fruits of varieties grown under organic farming conditions were obtained from a private farm at Nyíregyháza, in 2008 and 2009. The Érdi bőtermő, Újfehértói fürtös, Debreceni bőtermő, Kántorjános cultivars were grown both with organic farming and integrated conditions. The fruits of the variety $\mathrm{VN}$ were from a private farm in Vásárosnamény.

Csengődi, Oblacsinszka, Éva, Petri, VN-1, VN-4, VN-7, Pipacs, D, Pándy 278, Cigány 59 and Cigány 7/1 were 
cultivated with integrated farming conditions and requirements.

The free radical 1,1-diphenyl-2-picrylhydrazyl (DPPH) and standard Trolox, (6-hydroxy-2,5,7,8-tetramethylcromane-2-carboxylic acid) were obtained from Fluka (Buchs, Switzerland). Other reagents were of analytical grade and purchased from Reanal (Budapest, Hungary).

\section{Methods used}

Sour cherries fruits were washed and then the size and weight of 50 fruits was measured according to Hungarian Standard MSZ 967-1:1982. From approximately five kg sample one kg optimally ripened, sound fruit was selected, pitted and disintegrated using a Waring blender. The blended fruit sample was used in the different measurements and chemical analyses.

Soluble solids, titratable acidity $(\mathrm{mg} / \mathrm{kg}$ ) total polyphenols $\mathrm{mg} / \mathrm{kg}$ as gallic acid equivalent), free radical scavenging activity (TEAC: mmole/kg), copper and zinc $(\mathrm{mg} / \mathrm{kg})$ were measured as described previously (Tóth-Markus et al., 2010). The values from chemical analyses were fresh weight-related.

The values are given as means and standard deviation of triplicate samples. Principal component analysis was performed using Minitab software version 13,0 .

Sensory analysis was performed by a panel consisting of 10-16 assessors. The tasters (women and men) received training in the principles of sensory analyses according to ISO standards. Unstructured line scales of $10 \mathrm{~cm}$ anchored on the left side by the term 'none' and on the right side by the term 'extreme' were used for the scoring of each sensory term. Scoring was performed on a five points scale. Profiling and scoring data were collected using the PSA data acquisition software (OP \& P, Utrecht, Netherlands).

Statistical evaluation of sensory data: by SPSS 17 software using ANOVA for comparison of the average results of product properties.

\section{Results and Discussion}

Table 1 summarises the data obtained on fruit size and weight, while results obtained from chemical analyses for the different parameters with standard deviations are shown in Tables 2 and 3. From the data it is clear that the size and weight of sour cherry fruit depends rather on the genotype than the cultivation technology, however, fruits from some varieties such as Debreceni bőtermő , íkantorjanosi and Érdi bőtermő cultivated under organic farming conditions had larger size and average weight/piece higher than that of the fruits of the same varieties but cultivated under conventional conditions.

Total polyphenols and free radical scavenging activity was higher in VN and Cigány cultivars. From VN cultivars, VN-1 proved to be most outstanding. The amarelle-type Pipacs studied in 2009 had the highest polyphenol content among all varieties examined. Likely, in their work, Papp and co-workers (2010) have reported high total phenol content and antioxidant capacity in the fruits of the variety Pipacs1.

Table 1: Size and weight of sour cherries at harvest

\begin{tabular}{|c|c|c|c|c|}
\hline Cultivar & Date and provenance & $\begin{array}{l}\text { Avg. } \\
\text { size }\end{array}$ & $\begin{array}{l}\text { Avg.wt./ } \\
\text { piece with } \\
\text { stone }\end{array}$ & $\begin{array}{c}\text { Avg.wt./ } \\
\text { piece without } \\
\text { stone }\end{array}$ \\
\hline Érdi bőtermő bio & 2008. VI. 23. Nyíregyháza & 2.14 & 7.0 & 6.4 \\
\hline Érdi bötermő integrated & 2008. VI. 23. Újfehértó & 1.97 & 6.7 & 6.1 \\
\hline Érdi bőtermő integrated & 2009. VI. 15. Újfehértó & 2.1 & 6.5 & 5.9 \\
\hline $\mathrm{VN}-1$ & 2008. VI. 18. Vásárosnamény & 1.84 & 4.6 & 4.1 \\
\hline VN-7 & 2008. VI. 19. Vásárosnamény & 2.06 & 6.6 & 6.0 \\
\hline $\mathrm{VN}-4$ & 2008. VII. 1. Vásárosnamény & & & \\
\hline $\mathrm{VN}-1$ & 2009. VI. 08. Vásárosnamény & 1.8 & 4.6 & 4.2 \\
\hline $\mathrm{VN}-7$ & 2009. VI. 15. Vásárosnamény & 2.0 & 5.4 & 4.9 \\
\hline $\mathrm{VN}-4$ & 2009. VI. 15. Vásárosnamény & 1.85 & 4.71 & 4.1 \\
\hline Oblacsinszka & 2008. VI. 23. Újfehértó & 1.66 & 4.0 & 3.4 \\
\hline Csengődi integrated & 2008. VI. 23. Újfehértó & 2.03 & 5.8 & 5.1 \\
\hline Csengődi integrated & 2009. VI.15. Újfehértó & 1.88 & 5.3 & 4.6 \\
\hline Újfehértói fürtös bio & 2008. VII. 5. Nyiregyháza & 1.97 & 5.3 & 4.8 \\
\hline Újfehértói fürtös integrated & 2008. VII. 7. Újfehértó & 1.94 & 5.3 & 4.8 \\
\hline Újfehértói fürtös integrated & 2009. VI. 29. Újfehértó & 2.13 & 5.9 & 5.3 \\
\hline Újfehértói fürtös integrated & 2009. VII. 06. Újfehértó & 1.86 & 4.7 & 4.3 \\
\hline Újfehértói fürtös bio & 2009. VI. 29. Nyiregyháza & 2.26 & 6.7 & 6.0 \\
\hline Kántorjánosi bio & 2008. VII. 5. Nyiregyháza & 1.92 & 5.2 & 4.7 \\
\hline Kántorjánosi integrated & 2008. VII. 7. Újfehértó & 2.00 & 5.7 & 5.1 \\
\hline Kántorjánosi bio & 2009. VI. 29. Nyíregyháza & 2.25 & 6.6 & 6.0 \\
\hline Kántorjánosi integrated & 2009. VI. 29. Újfehértó & 2.23 & 6.1 & 5.5 \\
\hline Kántorjánosi integrated & 2009. VII. 06. Újfehértó & 1.89 & 5.9 & 5.3 \\
\hline Éva integrated & 2008. VII. 4. Újfehértó & 2.04 & 5.9 & 5.3 \\
\hline Éva integrated & 2009.VII. 06. Újfehértó & 1.91 & 6.1 & 5.4 \\
\hline Petri integrated & 2008. VII. 5. Újfehértó & 2.11 & 6.3 & 5.7 \\
\hline Petri integrated & 2009. VII. 06. Újfehértó & 2.05 & 6.1 & 5.5 \\
\hline Debreceni bötermő bio & 2008. VII. 5. Nyíregyháza & 2.11 & 6.4 & 5.8 \\
\hline Debreceni bőtermő integrated & 2008. VII. 3. Újfehértó & 2.09 & 5.7 & 5.2 \\
\hline Debreceni bőtermő bio & 2009. VI. 29. Nyiregyháza & 2.33 & 7.6 & 6.9 \\
\hline Debreceni bőtermő integrated & 2009. VI. 29. Újfehértó & 2.01 & 5.0 & 4.4 \\
\hline Debreceni bőtermő integrated & 2009. VII. 06. Újfehértó & 1.84 & 4.7 & 4.2 \\
\hline "D" integrated & 2009. VII. 06. Újfehértó & 1.97 & 6.3 & 5.6 \\
\hline Pipacs integrated & 2009. VII. 06. Újfehértó & 1.91 & 6.1 & 5.5 \\
\hline
\end{tabular}


Table 2: Titratable acidity and Brix degree of different varieties of sour cherry cultivated under conventional and organic farming conditions at different provenances.

\begin{tabular}{|c|c|c|c|}
\hline Cultivar & Date, provenance & Brix degree & Titratable acidity g/kg \\
\hline Érdi bőtermő bio & 2008. VI. 23. Nyíregyháza & 15.6 & $9.49 \pm 0.03$ \\
\hline Érdi bőtermő integrated & 2008. VI. 23.Újfehértó & 15.8 & $9.18 \pm 0.24$ \\
\hline Érdi bőtermő integrated & 2009. VI. 15. Újfehértó & 16.8 & $10.72 \pm 0.08$ \\
\hline VN-1 & 2008. VI. 18.Vásárosnamény & 20.5 & $11.24 \pm 0.75$ \\
\hline VN-1 & 2009. VI. 08. Vásárosnamény & 21.1 & $10.07 \pm 0.11$ \\
\hline $\mathrm{VN}-7$ & 2008. VI. 19. Vásárosnamény & 16.0 & $11.29 \pm 0.87$ \\
\hline VN-7 & 2009. VI.15. Vásárosnamény & 17.8 & $10.89 \pm 0.18$ \\
\hline $\mathrm{VN}-4$ & 2009. VI. 15. Vásárosnamény & 16.8 & $9.92 \pm 0.08$ \\
\hline Oblacsinszka & 2008. VI. 23. Újfehértó & 16.8 & $19.01 \pm 0.46$ \\
\hline Csengődi integrated & 2008. VI. 23. Újfehértó & 16.6 & $10.35 \pm 0.34$ \\
\hline Csengődi integrated & 2009. VI.15. Újfehértó & 15.9 & $9.17 \pm 0.22$ \\
\hline Újfehértói fürtös bio & 2008. VII. 5. Nyiregyháza & 17.8 & $14.72 \pm 0.08$ \\
\hline Újfehértói fürtös integrated & 2008. VII. 7. Újfehértó & 19.1 & $17.01 \pm 0.09$ \\
\hline Újfehértói fürtös integrated & 2009. VI. 29. Újfehértó & 18.0 & $14.02 \pm 0.26$ \\
\hline Újfehértói fürtös integrated & 2009. VII. 06. Újfehértó & 17.0 & $19.29 \pm 0.07$ \\
\hline Újfehértói fürtös bio & 2009. VI. 29. Nyiregyháza & 16.5 & $13.45 \pm 0.05$ \\
\hline Kántorjánosi bio & 2008. VII. 5. Nyiregyháza & 17.2 & $16.44 \pm 0.07$ \\
\hline Kántorjánosi integrated & 2008. VII. 7. Újfehértó & 18.9 & $13.48 \pm 0.09$ \\
\hline Kántorjánosi bio & 2009. VI. 29. Nyiregyháza & 17.3 & $14.96 \pm 0.18$ \\
\hline Kántorjánosi integrated & 2009. VI. 29. Újfehértó & 17.4 & $13.12 \pm 0.04$ \\
\hline Kántorjánosi integrated & 2009. VII. 06 Újfehértó & 16.1 & $14.36 \pm 0.34$ \\
\hline Éva integrated & 2008. VII.4. Újfehértó & 18.8 & $13.80 \pm 0.08$ \\
\hline Éva integrated & 2009.VII. 06. Újfehértó & 15.9 & $14.24 \pm 1.04$ \\
\hline Petri integrated & 2008. VII. 5. Újfehértó & 17.0 & $13.69 \pm 0.03$ \\
\hline Petri & 2009. VII. 06. Újfehértó & 15.6 & $14.28 \pm 0.74$ \\
\hline Debreceni bőtermő bio & 2008. VII. 5. Nyíregyháza & 15.4 & $11.08 \pm 0.02$ \\
\hline Debreceni bötermő integrated & 2008. VII. 3. Újfehértó & 18.5 & $12.57 \pm 0.09$ \\
\hline Debreceni bőtermő bio & 2009. VI. 29. Nyiregyháza & 15.5 & $11.92 \pm 0.19$ \\
\hline Debreceni bőtermő integrated & 2009. VI. 29. Újfehértó & 16.8 & $13.69 \pm 0.16$ \\
\hline Debreceni bötermő integrated & 2009. VII.06 Újfehértó & 16.1 & $13.12 \pm 0.12$ \\
\hline "D" integrated & 2009. VII.06 Újfehértó & 14.6 & $11.98 \pm 0.03$ \\
\hline Pipacs integrated & 2009. VII.06 Újfehértó & 20.2 & $21.34 \pm 0.32$ \\
\hline \multicolumn{4}{|l|}{ Storage in 2008} \\
\hline Érdi bőtermő integrated & 2008.VIII.2. Újfehértó & 18.2 & $6.70 \pm 0.03$ \\
\hline Újfehértói fürtös integrated & 2008.VIII.2. Újfehértó & 19.2 & $5.78 \pm 0.12$ \\
\hline Kántorjánosi integrated & 2008.VIII.2. Újfehértó & 17.3 & $6.54 \pm 0.01$ \\
\hline Éva integrated & 2008.VIII.2. Újfehértó & 18.5 & $7.84 \pm 0.12$ \\
\hline Petri integrated & 2008.VIII.2. Újfehértó & 16.9 & $6.95 \pm 0.18$ \\
\hline Debreceni bőtermő integrated & 2008.VIII.2. Újfehértó & 17.9 & $7.66 \pm 0.58$ \\
\hline
\end{tabular}

Both total phenols and antioxidant activity were lower in 2009 than the level found in2008. The total polyphenol content of the cultivars in the two seasons is shown in Figure 1. Similar results were published by Stracke and co-workers (2009) who made a three-year comparison of the polyphenol contents and antioxidant capacities in organically and conventionally produced (Golden Delicious) apple. Their main conclusion was that production method had a less impact on the variation in the polyphenol content and antioxidant capacity of apples than the impact of climate of the production season.
The storage potential of cultivars was investigated at $2^{\circ} \mathrm{C}$ and at normal atmosphere. Six cultivars from integrated farming (Érdi bőtermő, Újfehértói fürtös, Kántorjánosi, Éva, Petri, and Debreceni bőtermő) were included in the storage experiment. After storage for four weeks, acid content of sour cherries decreased drastically. Shrinkage of Érdi bőtermő sample as a consequence of water loss was the remarkable change during storage. Also, the average weight of one fruit decreased from $6,7 \mathrm{~g}$ to 5,77 $\mathrm{g}$ with marked increase in soluble solids (Brix). In case of Éva and Petri varieties, the average weight per piece, Brix and total polyphenols changed within measurement uncertainty, but titratable acidity markedly decreased and the sensorial quality parameters of the fruits showed substantial deterioration. The decrease of acid content was around $50 \%$. (changed from $27 \%$ to $54 \%$ in Érdi bőtermő). All stored fruits had an unpleasant, stale flavour. The polyphenol content and free radical scavenging capacity of stored fruits also decreased by 34 and 37\%, in Kántorjánosi and Újfehértói cultivars respectively. Szabó (2007) reported that there was no significant difference between the cultivars investigated regarding storability.

The dataset for the cultivar pairs produced under bio and integrated conditions were compared using principal component analysis based on correlation matrix. According to the loading plot (Figure 2) the first component is connected with the size of the fruit, antioxidant capacity, total phenolics, soluble solids (Brix) and acidity while the second factor was composed by concentration of copper and zinc. First two principal components explain $65 \%$ of the variability in the data.

The samples from different seasons are separated on principal analysis score plot (Figure 3). For the sake of transparency, only the bio-integrated sample pairs were plotted. In 2009, the bio orchard was severely damaged by hail, and fruits had to be immediately harvested. The integrated 'Debreceni bőtermő', 'Kántorjánosi' and 'Újfehértói' fruits were picked once together with bio samples, and also one week later at optimal ripeness. Figure shows that maturity change in one week makes a shift of points comparable to the effect of organic or integrated cultivation. Organic fruits had generally higher copper content. 
Table 3: Poly-phenols, antioxidant activity, and some mico-element content of different varieties of sour cherry cultivated under conventional and organic farming conditions at different provenances

\begin{tabular}{|c|c|c|c|c|c|}
\hline Cultivar & Date, provenance & Polyphenols mg/kg & DPPH mmol/kg & Copper mg/kg & Zinc mg/kg \\
\hline Érdi bőtermő bio & 2008. VI. 23. Nyíregyháza & $1380 \pm 51$ & $13.9 \pm 1.1$ & 1.09 & 0.39 \\
\hline Érdi bőtermő integrated & 2008. VI. 23.Újfehértó & $1413 \pm 76$ & $15.3 \pm 1.6$ & 0.66 & 0.29 \\
\hline Érdi bőtermő integrated & 2009. VI. 15. Újfehértó & $1232 \pm 10$ & $10.2 \pm 0.1$ & 0.48 & 0.35 \\
\hline VN-1 & 2008. VI. 18. Vásárosnamény & $3490 \pm 199$ & $32.2 \pm 2.1$ & & \\
\hline $\mathrm{VN}-1$ & 2009. VI. 08. Vásárosnamény & $3085 \pm 83$ & $26.3 \pm 0.3$ & & \\
\hline VN-7 & 2008. VI. 19. Vásárosnamény & $2156 \pm 104$ & $22.4 \pm 0.8$ & & \\
\hline VN-7 & 2009. VI. 15. Vásárosnamény & $2175 \pm 15$ & $19.3 \pm 0.4$ & & \\
\hline VN-4 & 2008. VII. 1. Vásárosnamény & $2134 \pm 42$ & $23.5 \pm 1.3$ & & \\
\hline VN-4 & 2009. VI. 15. Vásárosnamény & $1748 \pm 106$ & $14.50 \pm 1$ & & \\
\hline Oblacsinszka & 2008. VI. 23. Újfehértó & $2551 \pm 22$ & $23.1 \pm 0.4$ & & \\
\hline Csengődi integrated & 2008. VI. 23. Újfehértó & $2326 \pm 86$ & $22.5 \pm 0.1$ & & \\
\hline Csengődi integrated & 2009. VI. 15. Újfehértó & $1628 \pm 20$ & $12.5 \pm 0.3$ & 0.42 & 0.43 \\
\hline Újfehértói fürtös bio & 2008. VII. 5. Nyiregyháza & $1928 \pm 40$ & $19.8 \pm 1.2$ & 0.94 & 0.19 \\
\hline Újfehértói fürtös integrated & 2008. VII. 7. Újfehértó & $1645 \pm 38$ & $16.2 \pm 1$ & 0.94 & 0.41 \\
\hline Újfehértói fürtös integrated & 2009. VI. 29. Újfehértó & $1430 \pm 21$ & $13.9 \pm 0.7$ & 0.48 & 0.36 \\
\hline Újfehértói fürtös integrated & 2009. VII. 06. Újfehértó & $1513 \pm 36$ & $15.3 \pm 0.6$ & 0.69 & 0.34 \\
\hline Újfehértói fürtös bio & 2009. VI. 29. Nyiregyháza & $1352 \pm 10$ & $11.2 \pm 0.3$ & 0.75 & 0.24 \\
\hline Kántorjánosi bio & 2008. VII. 5. Nyiregyháza & $1732 \pm 43$ & $19.8 \pm 0.4$ & 1 & 0.27 \\
\hline Kántorjánosi integrated & 2008. VII. 7. Újfehértó & $1915 \pm 89$ & $20.5 \pm 1.7$ & 0.9 & 0.26 \\
\hline Kántorjánosi bio & 2009. VI. 29. Nyiregyháza & $1376 \pm 14$ & $12 \pm 0$ & 0.80 & 0.26 \\
\hline Kántorjánosi integrated & 2009. VI. 29. Újfehértó & $1198 \pm 4$ & $11.2 \pm 0$ & 0.43 & 0.28 \\
\hline Kántorjánosi integrated & 2009. VII. 06. Újfehértó & $1422 \pm 221$ & $15.5 \pm 0.8$ & 0.52 & 0.26 \\
\hline Éva integrated & 2008. VII. 4. Újfehértó & $1639 \pm 3$ & $18.5 \pm 0.2$ & 0.89 & 0.71 \\
\hline Éva integrated & 2009.VII. 06. Újfehértó & $1207 \pm 9$ & $13.7 \pm 0.1$ & 0.58 & 0.70 \\
\hline Petri integrated & 2008. VII. 5. Újfehértó & $1548 \pm 42$ & $16.8 \pm 1$ & 0.82 & 0.41 \\
\hline Petri & 2009. VII. 06. Újfehértó & $1388 \pm 59$ & $14.5 \pm 0.8$ & 0.49 & 0.31 \\
\hline Debreceni bőtermő bio & 2008. VII. 5. Nyíregyháza & $1283 \pm 58$ & $15.2 \pm 1$ & 0.97 & 0.33 \\
\hline Debreceni bőtermő integrated & 2008. VII. 3. Újfehértó & $1689 \pm 98$ & $18 \pm 1$ & 0.87 & 0.43 \\
\hline Debreceni bőtermő bio & 2009. VI. 29. Nyíregyháza & $1033 \pm 42$ & $9.8 \pm 0.3$ & 1.056 & 0.36 \\
\hline Debreceni bőtermő integrated & 2009. VI. 29. Újfehértó & $1009 \pm 39$ & $11 \pm 2$ & 0.40 & 0.32 \\
\hline Debreceni bőtermő integrated & 2009. VII. 06. Újfehértó & $1352 \pm 17$ & $9.8 \pm 0.4$ & 0.55 & 0.36 \\
\hline "D" integrated & 2009. VII. 06. Újfehértó & $1442 \pm 165$ & $13.4 \pm 1$ & 0.51 & 0.41 \\
\hline Pipacs integrated & 2009. VII. 06. Újfehértó & $6230 \pm 181$ & $58.4 \pm 0.5$ & 0.69 & 0.29 \\
\hline Pándy 279 & 2008. VII. 01. Újfehértó & $1266 \pm 889$ & $13.2 \pm 0.4$ & & \\
\hline Cigány 59 & 2008. VI. 30. Újfehértó & $2217 \pm 34$ & $21.6 \pm 0$ & & \\
\hline Cigány $7 / 1$ & 2008. VI. 30. Újfehértó & $1803 \pm 66$ & $19.2 \pm 1.9$ & & \\
\hline \multicolumn{6}{|l|}{ Storage in 2008} \\
\hline Érdi bőtermő integrated & 2008. VIII. 2. Újfehértó & $1354 \pm 2$ & $13.9 \pm 0.5$ & & \\
\hline Újfehértói fürtös integrated & 2008. VIII. 2. Újfehértó & $1030 \pm 39$ & $10.5 \pm 1.4$ & & \\
\hline Kántorjánosi integrated & 2008. VIII. 2. Újfehértó & $1269 \pm 32$ & $12.4 \pm 0.5$ & & \\
\hline Éva integrated & 2008. VIII. 2. Újfehértó & $1614 \pm 32$ & $16.2 \pm 0.8$ & & \\
\hline Petri integrated & 2008. VIII. 2. Újfehértó & $1535 \pm 94$ & $14.8 \pm 1$ & & \\
\hline Debreceni bőtermő integrated & 2008. VIII. 2. Újfehértó & $1550 \pm 49$ & $14.8 \pm 1$ & & \\
\hline
\end{tabular}

Before the sensory test, the training of experts and the selection of descriptors happened according to relevant MSZ ISO standards.

The assessors (women and men) could not find a significant difference between sour cherry varieties except for Pipacs, which was characterised with a tart, bitter, sour taste. Panel members preferred Éva and Petri varieties.
Organic and integrated sample pairs were also compared and panel members preferred the integrated ones in crop year 2008. Figure 4 shows the sensory profile of organic and integrated 'Kántorjánosi' cultivar.

These results are considered as preliminary, as the experiment is continued in summer 2010. 


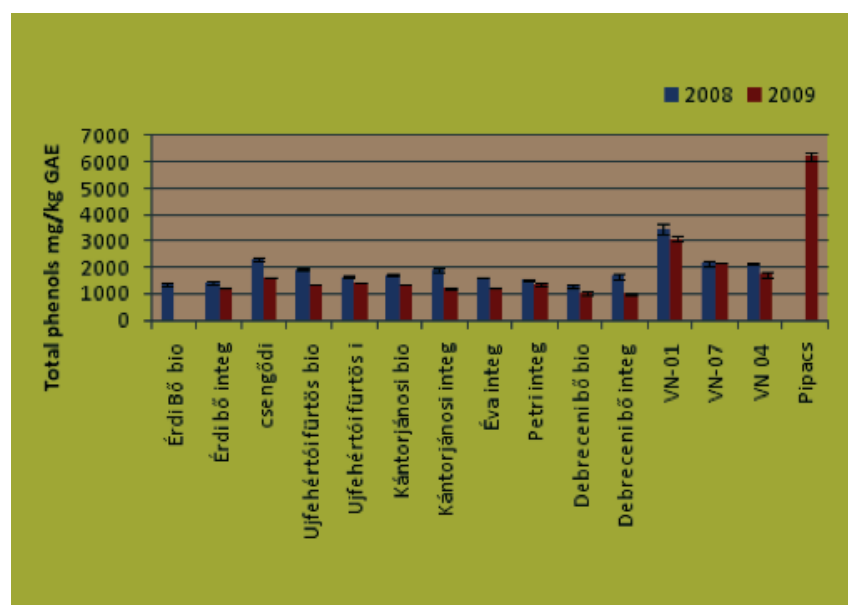

Figure 1: Total phenols of sour cherries in the cultivation seasons of 2008 and 2009.

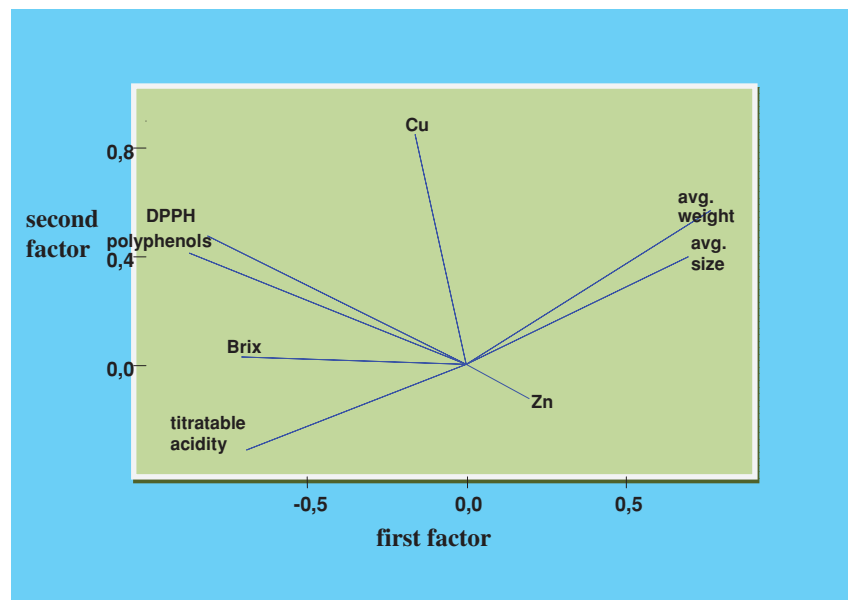

Figure 2: Principal component analysis, loading plot of sour cherry data

\section{References}

MSZ 9697-1:1982 Gyümölcsök vizsgálata. Általános előírások (Testing of fruits. General specifications)

MSZ ISO 8586-1:2001 General guidance for the selection, training and monitoring of assesors. Part 1: Selected assessors

MSZ EN ISO 8586-2:2008 General guidance for the selection, training and monitoring of assesors. Part 2: Experts

MSZ ISO 11035:2001 Identification and selection of descriptors for establishing a sensory profile by a multidimensional approach

MSZ ISO 6564:2001 Flavor profile methods

Papp N, Szilvássy B, Abrankó L, Szabó T, , Pfeiffer P, Szabó Z, Nyéki J, Ercisli S, Stefanovits-Bányai É, Hegedús A. (2010): Main quality attributes and antioxidants in Hungarian sour cherries: identification of genotypes with enhanced functional properties

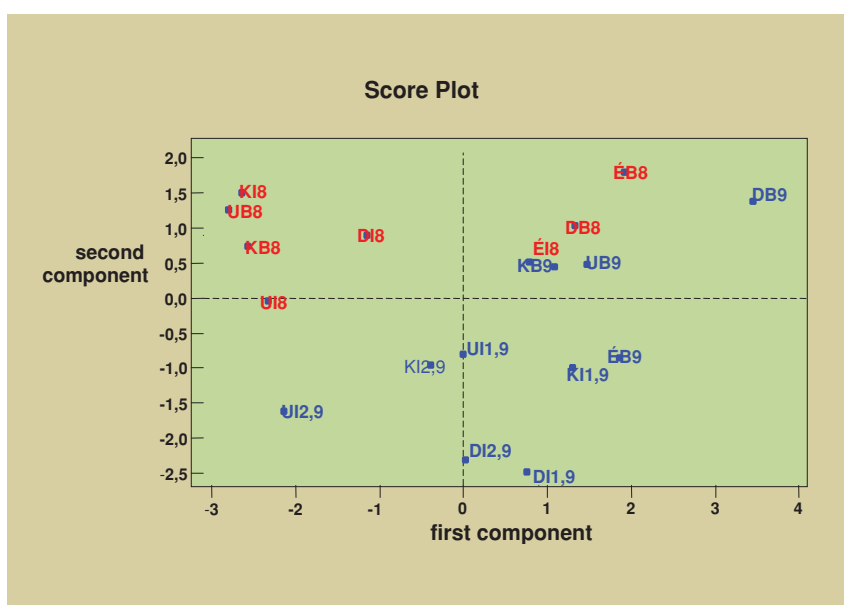

Figure 3: Principal component analysis, score plot of sour cherry data

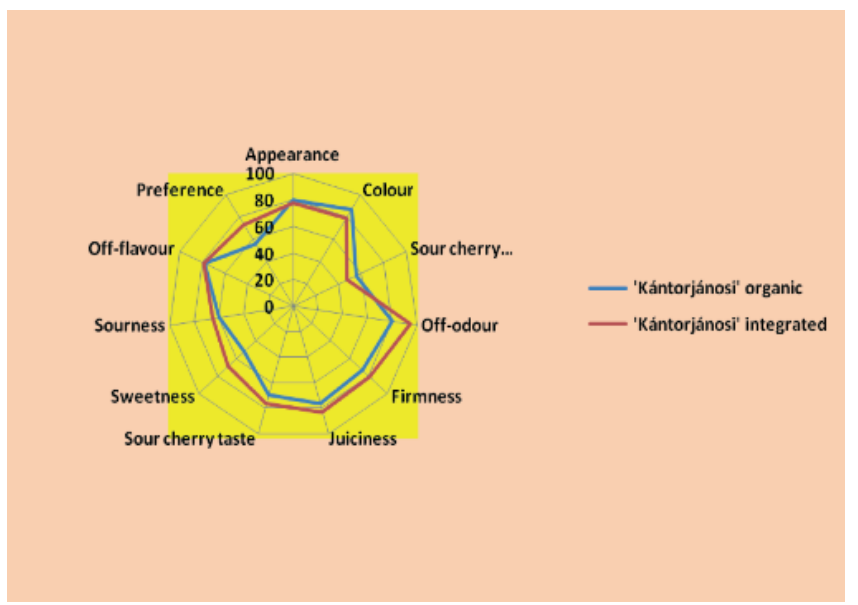

Figure 3: Principal component analysis, score plot of sour cherry data

International Journal of Food Science \& Technology, 45 (2): 395402.

Stracke BA, Rüfert CE, Weibelß FP, Bub A, Watzl B (2009): Three-year comparison of the polyphenol contents and antioxidant capacities in organically and conventionally produced apples (Malus domestica Bork. Cultivar 'Golden Delicious'. Journal of Agricultural and Food Chemistry, 57: 4598-4605.

Szabó T. (2007): Az Északkelet-Magyarországi meggy tájfajta szelekció eredményei és gazdasági jelentősége. Budapesti Corvinus Egyetem, $\mathrm{PhD}$ dolgozat. The results and economic significance of sour cherry cultivars' landrace selection in North-East Hungary. PhD thesis, pp. 106-109.

Tóth-Markus M, Adányi N, Boross F, Daood HG, Bánáti D, Szabó T, \& Nyéki J. (2010): Comparison of apples from organic and integrated farming. International Journal of Horticultural Science, 16: (3). in press 